\title{
Global communication and political culture in the semi-periphery: the rise of the Globo corporation
}

\author{
PETER WILKIN
}

\begin{abstract}
This article will offer a description and explanation of the rise of the Brazilian media corporation Globo by situating it in the context of the periphery and semi-periphery of the World System and the globalisation of communication. In particular it focuses upon the changing role that Globo has played in the construction of an elite-led political culture in Brazil that has moved through phases of authoritarian and democratic government. The article sets out an historical account of the emergence of Globo from being a regional media organisation in the periphery of the world system to a global broadcaster in the semi-periphery. It moves through three phases: First, 1925-1964, the colonial legacy and Brazil in the periphery; second, 1964-1985, a period of transition and conservative modernisation, into the semi-periphery; and finally, 1985 onwards, the age of globalisation.
\end{abstract}

\section{Introduction}

The aim of this article is to provide a description and explanation of the rise of the Brazilian media corporation Globo by situating it in the context of the periphery and semi-periphery of the world system. In particular it focuses upon the changing roles that Globo has played in the construction of an elite-led political culture in Brazil that has moved through phases of authoritarian and democratic government. I will begin with a brief discussion of the concept of the semi-periphery and its relevance for the discussion of Globo that follows. I will then turn to an historical account of the emergence of Globo from being a regional media organisation to a vertically and horizontally integrated global corporation with interests in: horizontal - film, music, television, print, radio, telecommunications' and the internet; vertical-property, banking, manufacturing, insurance and construction, employing overall around 23,000 people. ${ }^{1}$

In this article I will focus on three major issues in Globo's history and how they relate, in turn, to the political economy of global communication. The first of these is the importance of Globo in the development of Brazilian political culture and how this has evolved from a largely domestic nation-building agenda to an increasingly global focus reflecting the transition in the 1990s from the Cold War to an era of neoliberal governance. The second factor is that most work on global communication

\footnotetext{
${ }^{1}$ Ketupa.net: A media industry resource, 'Globo', 〈http://www.ketupa.net/globo.htm〉, last viewed 20
} April 2006. 
has tended to focus upon media based in the core rather than the semi-periphery. Globo is a corporation based in a state that has moved from the periphery to the semi-periphery over the course of its history, developing increasingly important links with core based corporations and capital. What this illustrates is that this development does not in itself do anything to remove the dependent nature of Globo's relationship to the core. Instead it renders it only more complex and intertwined with the fortunes of the core. Finally I will also clarify the ways in which Globo has become a major media actor with a global cultural reach, producing programmes for a worldwide market and making tentative efforts to invest in sectors of the core. Globo is an important case because it highlights the strengths and weaknesses of corporations based in the semi-periphery of the world system.

The article situates Globo in what I see as three distinct phases for Brazil in the world system. First, 1925-1964, the colonial legacy and Brazil in the periphery; second, 1964-1985, a period of transition and conservative modernisation, into the semi-periphery; and finally, 1985 onwards, the age of globalisation. These three periods see Brazil move from the periphery to the semi-periphery of the world system, and Globo evolve from an important national and regional media company to become a global broadcaster with major cultural capital and increasingly important links with global media companies from the core. The route of Globo's development reflects Brazil's integration into the capitalist world system. I will conclude by looking at the major challenges to Globo in the $\mathrm{C} 21$ and by extension the issues that this raises for the political economy of global communication.

\section{Communication in the semi-periphery}

'Yes, I use this power . . . always in a patriotic way, trying to correct things, seeking paths for the country and its states'.

Roberto Marinho, The New York Times, 1987.2

'In ancient Rome, only the Romans voted. In modern global capitalism, only the Americans vote, not the Brazilians'.

George Soros, Folha de S. Paulo, 2002. ${ }^{3}$

Why, then, is World-Systems Analysis (WSA) a better way of interpreting Globo's development, mass communication and global political economy than its orthodox theoretical alternatives, realism and liberalism? Whilst there is not space to go into a lengthy debate here about these issues it is useful to illustrate the strengths of WSA when compared to realism and liberalism by focusing upon three areas:

\section{Historical structures}

WSA emphasises that the modern world system is just that, a system with an origin and trajectory that develops over time and within which there are important

2 Luis Felipe Miguel and Paolo Simoes, 'The Globo Television Network and the Election of 1998', Latin American Perspectives, 27:115, no. 6 (2000), p. 69.

3 Soros quoted by Steven Dudley, 'Lula Needs a Miracle', The Progressive, October 2002: 〈http://www.findarticles.com/p/articles/mi_m1295/is_10_66/ai_93457090〉, last viewed 18 April 2006. 
qualitative social, political and economic developments. In particular, WSA provides a persuasive account of the causes of inequality and uneven development in the world system. This explanation is rooted in the historical structures of a system that has divided the world into a core, periphery and semi-periphery, patterns of uneven development that reproduce themselves not only as zones that structure the world system through a division of labour but that also increasingly reflect patterns of inequality within states. By comparison liberalism and realism in their contemporary forms tend to eschew a concern with questions of history (neorealism) or structure (neoliberalism) and therefore lack the theoretical tools to provide a deep understanding of the development of the world system. ${ }^{4}$

\section{Unidisciplinarity}

As the Fernand Braudel Centre have persistently argued, 'In this light, we believe that the problem is not to find an interdisciplinary meeting ground of the study of historical sequence (history) and the study of structures (anthropology, sociology, and other social sciences). It is to perceive our study as an imbricated whole with a single theoretical framework, within which different scholars will of course emphasise different immediate concerns and therefore frequently use different approaches, emphases, methodologies ... We are further uncomfortable with the traditional divide of humanities versus the (social) sciences. At least at the level of explaining large-scale social change over time, we find that it is not very meaningful to distinguish between a humanistic and a scientific approach. We wish primarily to explain systematically and coherently what is fundamentally a single occurrence, the development of the modern world-system.'5 WSA is important for international relations because it advocates a unidisciplinary approach to the social sciences. As the above quote illustrates, the traditional academic disciplines have served to obscure rather than aid understanding of the social world.

By contrast, neorealism wants to preserve the idea that politics and high politics in particular are distinct areas of study and practice whilst neoliberals try to separate politics and economics in theory and practice. ${ }^{6}$ The consequence of this is that both of the latter provide limited accounts of the ways in which politics and economics shape the world system and tend to ignore culture altogether.

\section{Globalisation}

The emergence of globalisation as both a description of and a theoretical approach to international relations was preceded by WSA by nearly twenty years. The idea that the world has become integrated into a complex whole is one that has been examined by WSA since its inception and it has produced a wide-ranging body of work over the

\footnotetext{
${ }^{4}$ On the theoretical limitations of neorealism and neoliberalism, see Peter Wilkin, 'Global Poverty and Orthodox Security', Third World Quarterly, 23:4 (2002), pp. 633-45.

5 Fernand Braudel Center, Newsletter no. 30, November 2006.

${ }^{6}$ Michael W. Doyle, Ways of War and Peace: Liberalism, Realism and Socialism (New York: W. W. Norton, 1997).
} 
past thirty years to explore what this means for all areas of social life. ${ }^{7}$ Both liberalism and realism treat globalisation as a recent phenomenon whilst WSA offers detailed historical accounts of the rise of the modern world system as a single global unit.

According to WSA the semi-periphery plays a crucial part in stabilising the world system. It does this by providing the possibility of progress or development for all states, from the periphery, to the semi-periphery and ultimately the core. The ideological aspect of this developmental doctrine is reflected in the theoretical belief that all states can 'develop' in this way. The reality is that the dynamic of global capital accumulation means that they cannot, as it is fundamentally a system where the core exploits both the periphery and semi-periphery, producing patterns of uneven development. Development and government policy in the periphery and the semi-periphery is ultimately subordinate to and dependent upon the actions of the core. For example, the debt crisis that hit much of the periphery and the semiperiphery in the 1980s and which persists today is a good example of this as it was the direct result of a major interest rate hike by the US Federal Reserve Board in the period 1979-1981, known as the 'Volcker shock'. Paul Volcker then, chairman of the Federal Reserve Board, raised US interest rates from 9 per cent in October 1979 to 21.5 per cent in January 1981. The impact of this policy was brutal for the working class in the core but devastating for those in much of the periphery and the semi-periphery (such as Brazil) where cheap loans from banks in the Core had been a major mechanism to stimulate growth and development in the previous decade. As Branford and Kucinski note, the impact of these interest rate increases by the US Federal Reserve Board was to raise Brazil's interest rate bill by 250 per cent from 1979 to $1982 .{ }^{8}$ The control of credit and finance remains a major mechanism of control for the core over the rest of the world system, as former US Government economic advisor Michael Hudson has written. ${ }^{9}$

The development of communication within the world system has occurred on four interlocking levels: local, national, regional and global. The global framework for this has been constructed through the efforts of the core states from the laying of telegraphy cables to the introduction of the Internet. It is the core that has directed these developments either with the consent of subordinate partners in the periphery and the semi-periphery or during its phases of direct imperial control in the C19 and C20. The structure of global communication has been to sustain what is often referred to as the 'digital divide' whereby the core dominates the production, distribution and consumption of communication goods and services. ${ }^{10}$ This divide provides the core with different forms of power over the world system:

1. Technological: The core dominates the production, distribution and control of new Information and Communication Technology (ICT).

2. Ideological: The core dominates the production, distribution and consumption of global news and information through its news agencies, media corporations and control of the Internet.

${ }^{7}$ For a critical view on WSA, see Robert J. Holton, Globalisation and the Nation State (London: Macmillan, 1998).

${ }^{8}$ Sue Branford and Bernard Kucinski, The Debt Squads (London: Zed Books, 1988), p. 95.

9 Michael Hudson, Super Imperialism (London: Pluto Press, 2003).

${ }^{10}$ Hamid Mowlana, Global Communication in Transition (London Sage, 1996), ch. 1; Dayan Thussu, International Communication (London: Arnold, 2000), ch. 1. 
3. Cultural: The core dominates the production, distribution and consumption of global cultural goods and services from cinema to television. Even in an age where significant cultural industries have emerged in India, Brazil and Mexico, it is the core that shapes the international agenda for the regulation of communication markets.

4. Financial: It remains the finances of the core that dominate investment in the global communication industries. The case of Globo that I set out in this article is illustrative of this point. Even a company as important as Globo is still restricted by the instability of its position in the semi-periphery.

Throughout the world system mass communication has performed a number of similar roles. It has been a crucial factor in nation-building and the Brazilian military saw this as Globo's key role after the coup in 1964. Thus the means of communication have been central to the production, reproduction and transformation of social relations throughout the world system by attempting to promote forms of shared identity (imagined community) and constructing common news and cultural agendas.

One of the key differences between the core and the semi-periphery on the issue of mass communication concerns the types of government to be found in each zone. The semi-periphery has tended thus far to move between democratic and authoritarian forms of government who have often sought to use the means of communication as a mechanism of explicit propaganda control over the subordinate and oppositional sectors of the population, usually backed up with state violence. One consequence of this is that the experience of journalists in the semi-periphery is far more dangerous than that of those working in the core. Being a critical voice in the Brazilian or Mexican media can get you killed. That said, even on the issue of propaganda it needs to be stressed that the division between core and semi-periphery is a continuum rather than a clear divide. The media in the core frequently serve propagandistic purposes as the ongoing War on Terror has been shown to illustrate. ${ }^{11}$

The means of communication in Brazil have been shaped by the countries particular place in the structure of the world system since the C16. The most important factors affecting Brazil's evolution have been: its geographic size and relatively low population levels for much of its history; the concentration of populations around the east coast; the dominance of the military in Brazilian political culture; the extremes of inequality and poverty that have limited the domestic market in Brazil; its political dominance by the USA as the regional hegemon in Latin America; its economic underdevelopment and historical dependence on the core for investment.

Thus WSA provides a framework for understanding the uneven and dependent nature of core, periphery and semi-periphery relations within the world system, a framework that serves as the basis for empirical study. An important factor to remember and one that is often overlooked by its critics is that WSA expects to see movement within the world system. Membership of the core changes over time and the largest semi-periphery states such as China, India and perhaps Brazil have the potential to move into the core given their relative resources and/or regional dominance.

11 Philip M. Taylor, Munitions of the Mind (Manchester: Manchester University Press, 2003). 


\section{Building Globo in the periphery: the colonial legacy, 1925-1964}

The newspaper 'O Globo' was founded by Irenau Marinho in 1925 but was taken over almost immediately upon his death by his son Roberto Marinho. The latter became the driving force behind the development of Globo as a major media corporation. For the first 40 years of its existence the company was one of a number of competing media outlets in Brazil, certainly not pre-eminent. Its original ownership structure was similar to that of media corporations in many core states: family dominated. The family pattern of ownership of media corporations was also a familiar one throughout the South American periphery and this has remained the case until recently. The last decade has seen Globo and other South American media corporations such as Televisa (Mexico) change their patterns of ownership as they become more firmly integrated into the capitalist world system. The main reason for this has been the globalisation of financial and media markets that has intensified the need to attract foreign investment for companies in the semi-periphery. I will turn to this in more detail in the final section of the article.

In this early phase Marinho sought to ensure that there was a degree of critical distance between Globo, the state and existing political parties. In this respect Globo played the role of Fourth Estate in a system where the boundaries were shaped by the political struggles between elite-led liberal and conservative political parties, both of which were pro-capitalist but with differing strategies for the development of Brazil. The liberal fraction favoured integration into the world system whilst the conservative fraction sought protection from it. Nonetheless, given the social and elite background of the Marinho family, Globo was always a part of the governing structure of Brazil and supportive of the liberal capitalist model. Like mainstream media corporations in the core Globo was able to criticise existing institutions within limits. The overriding goal of such criticisms was to preserve a public realm for the dominant classes in Brazilian society to maintain its hold over politics, land and property.

In this period Brazil was a country struggling with its colonial past that saw it trapped into an uneven process of development. Whilst parts of Brazil's economy were making significant inroads towards industrialisation (the south-east in particular) much of the country remained dominated by feudal structures of economic production based around agriculture. Overall Brazil lacked the pre-requisites of meaningful nationhood: a viable transport and communication infrastructure and a national media that might help establish the idea of Brazil as an 'imagined community'. ${ }^{12}$

The state itself proved to be a mixture of strength and weakness in this period. Its strength was reflected in its aspirations to establish a corporatist political culture that would enable elites to work together in order to shape the direction of Brazilian development, manifesting itself in a series of shifts between dictatorship and democracy. The Vargas regimes (1937-1945) are perhaps the most well known example of this 'authoritarian populism' and Brazil's corporatism owed something to fascist ideology with its emphasis upon an elite-led political system that protected the

12 Jose Marques de Melo, 'Development of the Audiovisual Industry in Brazil', Canadian Journal of Communication, 20:3 (1995), 〈http://www.cjc-online.ca/viewarticle.php?id=303\&layout=html $\rangle$, last viewed 20 April 2006. 
position of the dominant social classes against the poor that continue to make up the majority of Brazil's population. ${ }^{13}$ At the same time, the weakness of the state was reflected in Brazil's constitutional structure and the conflict amongst elites over the modernisation of Brazil. ${ }^{14}$ Although the President has always possessed strong formal powers, in practice the decentralised nature of Brazil's federal system and its semi-autonomous geographical regions meant that local elites at the state level were largely able to resist moves by the federal government for greater control over national developmental projects. ${ }^{15}$ Brazil's political system and the absence of long-standing party political structures with their roots in social movements meant that political power rested upon a complex and shifting array of alliances between elite groups. The impact of these structures was to produce and reproduce a deeply corrupted political system within which the state was split between its need to build alliances with fractions of Brazil's elites, in patron-client manner, and the need to pursue what it saw as its national developmental goals. It is within this context that Globo began to develop.

Globo's business strategy was a mixture of specific goals and contingent opportunities. Marinho cultivated links with politicians as part of Globo's drive to expand its interests and a number of developments worked in its favour in this period. First, Globo secured radio station licences in 1944 enabling it to move into the realm of broadcasting thus expanding its reach within Brazil. Second, and crucially, in 1957 it gained its first licence to broadcast TV programmes. Again, it must be stressed that at this stage Globo was not the pre-eminent TV broadcaster in Brazil (that was its then rival TV Tupi, the first TV broadcaster in South America, which eventually closed in 1980) and ultimately it was the geopolitics of the Cold War that provided the opportunity for Globo to seize its dominant cultural position.

In 1960 Quadros was elected President of Brazil and he quickly antagonised senior military officers and the US administration of President Kennedy. The military feared that he had the ambition to become a populist dictator who would use his popular support to challenge existing social structures. Military intervention has a long history in Brazil, dating back to the monarchist period (1822-1889) and the Old Republic (1889-1930). ${ }^{16}$ Despite the populist pretensions of the Quadros administration Globo was able in 1962 to sign a secret and ultimately illegal deal with the US firm 'Time Life' that was to prove the key to its domination of Brazilian broadcasting. The deal gave Globo financial investment of around \$US6 m and key technical support enabling it to produce the high-quality programming that is associated with the company. In addition, 'Time Life' worked with the CIA to direct advertising to Globo, enabling Globo to develop a nationwide advertising cartel. Most advertising agencies in Brazil at the time were branches of US multinationals. ${ }^{17}$

13 Emir Sader and Ken Silverstein, Without Fear of Being Happy: Lula, The Workers Party and Brazil (London: Verso, 1991), p. 12; Robert J. Alexander, The ABC Presidents (London: Greenwood Press, 1992), pp. 91-116; Thomas E. Skidmore, Politics in Brazil 1930-64 (New York: Oxford University Press, 1967), pp. 3-142.

14 Alfredo Saad-Filho, 'New Dawn or False Start in Brazil?', Historical Materialism, 11:1 (2003), p. 8.

15 De Melo, 'Development of the Audiovisual Industry in Brazil'.

16 The Archdiocese of São Paolo, Torture in Brazil: A Shocking Report on the Pervasive use of Torture by Brazilian Military Governments, $1964-1979$ (Austin, TX: University of Texas Press, 1998), p. 41.

17 James S. Henry, The Blood Bankers: Tales from the Underground Global Economy (New York: Four Eight Walls, 2003), p. 137. See also John Sinclair, Latin American Television: A Global View (Oxford: Oxford University Press, 1999), pp. 66-9. 
In return for this 'Time Life' was meant to gain a significant stake in the company. With this huge advantage over its rivals Globo was able to begin broadcasting on 26 April 1965, from a single station in Rio de Janeiro. By 1972 Globo had stations in many major cities such as Sao Paolo, Belo Horizonte, Brasília and Recife. By 2003 this number had risen to 113 TV stations throughout Brazil. ${ }^{18}$ From its beginning TV Globo produced local and national programming in a fashion that has become synonymous with the company: light entertainment, comedy and populist rather than factual or educational, in spite of a constitutional requirement for balanced programming from broadcasters. ${ }^{19}$ It is a common observation that there is a dearth of factual programming in South American broadcasting. Perhaps the most persuasive explanation for this is that rather than it being due to a lack of popular demand it is more a reflection of the vulnerability of media institutions to state power in the periphery and semi-periphery. Factual programming in Brazil that exposes government corruption can get you killed, as a number of journalists for Globo's competitors found out in the 1970s. This is hardly an incentive for investigative reporting.

Quadros unexpectedly resigned the Presidency in 1962 to be replaced by his more progressive Vice-President Jose Goulart who put forward a national developmental model (known as the movement for 'basic reforms') proposing policies such as a new educational structure for all, land reform, the nationalising of utilities and oil refineries, encouraging soldiers to establish a union and legislation to control the repatriation of profits by foreign MNCs. ${ }^{20}$ The popularity of the Goulart administration posed similar problems for US foreign policy and sections of Brazil's military and social elites to those of his predecessor Quadros.

\section{Into the semi-periphery, 1964-1985: Globo in the period of conservative modernisation}

The 1964 Coup in Brazil that ushered in a 20-year period of military dictatorship was a result of two major factors: first, it was an attempt by a section of Brazil's elite to resolve the tensions and contradictions of Brazil's political culture, torn as it was between the more nationally oriented conservative elite and an internationally oriented liberal stratum. ${ }^{21}$ The military believed that only through a state-led developmental strategy could Brazil hope to resolve these tensions and take advantage of its potential human and natural resources to transform the country into a modern industrial state. This policy was two-fold: first, liberalisation of the economy to attract foreign investment, a policy which subsequently led to systematic and large-scale corruption between Brazilian elites and North American banks. Second, the concentration of incomes, intended to make Brazil more attractive to foreign investors by increasing their profit ratios and reducing the level of taxation

18 Allesandra Dalevi, 'The Owners of Brazil', Brazzil Magazine, January 2000, 〈http:// www.brazzil.com/cvrjan00.htm〉, last viewed 18 April 2006.

19 Ibid.

20 Henry, The Blood Bankers, pp. 132-7.

21 Thomas Skidmore, The Politics of Military Rule in Brazil, 1964-1985 (New York: Oxford University Press, 1988). 
that might, in turn, be spent on Brazil's poor and needy. So unpopular were these policies with the majority of Brazil's impoverished citizens that they could ultimately only be imposed by force. ${ }^{22}$ Hence this became a process of conservative modernisation that sought to balance out Brazil's national developmental needs without fundamentally challenging its polarised social structure. ${ }^{23}$ The liberal right had won out over the nationalist right in Brazil. ${ }^{24}$ Brazil's new developmental policy was to be an alliance between an authoritarian state, domestic capital and foreign capital. ${ }^{25}$ In short, a bureaucratic-capitalist pact. ${ }^{26}$ Second, the coup was a product of the geopolitics of the Cold War. Successive US administrations saw the need to support pro-capitalist social forces in Brazil and throughout South America that would remain loyal to broader US geopolitical and economic goals. What, then, did conservative modernisation mean for Globo and Brazil?

Unlike dictatorships in the rest of South America, the Brazilian military were wary of moving towards a political system led by a strong or charismatic figure, as had been the case in neighbouring Argentina, for example. The military regimes in Brazil imposed a governing structure which saw a succession of Generals' ruling in this period as part of a collective structure. ${ }^{27}$ In addition the infrastructure of Brazil needed to be developed in terms of ideational factors, a sense of collective national identity. And it is this aspect of conservative modernisation that enabled Globo to cement its place as the pre-eminent broadcaster in Brazil.

Marinho very quickly moved to work with the military and provide ideological support for and justification of the coup, branding the Goulart regime and the politicians associated with it such as future presidential candidate Lionel Brizola as communists in disguise. This 'red scare' strategy was a standard propaganda tool for Globo in this period. Brazilian critics of Globo described it as the unofficial 'ministry of information', acting as a mouthpiece for the military regime, defending its record against a wide section of critics in what remained of Brazilian civil society. In return for its loyal support Globo gained a number of important advantages. First, it gained licences for radio and TV broadcasting that were denied to its competitors, giving it a major structural advantage in the developing Brazilian market. ${ }^{28}$ TV Excelsior, for example, was effectively killed off by the military regime in the 1960s. ${ }^{29}$ Second, as the key media institution supporting conservative modernisation, it became synonymous with Brazilian popular and political culture. To speak of TV in Brazil was and is to speak of Globo. Its competitors complained that Globo had gained anti-competitive market advantages through its relationship with the military and this was reflected in its deal with 'Time Life'. In 1967 the Brazilian Supreme Court duly declared the 'Time Life' deal illegal and Globo had to repay its loan to the company, which it did

\footnotetext{
22 The Archdiocese of São Paolo, Torture in Brazil, pp. 49-52; Henry, The Blood Bankers, pp. 134-5.

23 Timothy J. Power, The Political Right in Post-Authoritarian Brazil (Pennsylvania, PA: The Pennsylvania State University Press, 2000).

24 Henry, The Blood Bankers, ch. 4

25 Peter Evans, Dependent Development: The Alliance of Multinational, State and Local Capital in Brazil (Princeton, NJ: Princeton University Press, 1979).

${ }^{26}$ Luis Carlos Bresser Pereira, Economic Crisis and State Reform in Brazil (Boulder, CO: Lynne Rienner, 1996), pp. 210-11.

27 Craig L. Arcenaux, Bounded Missions (Pennsylvania, PA: Pennsylvania State University Press, 2001), ch. 5. Skidmore, Politics in Brazil, chs. 7-8.

28 Henry, The Blood Bankers, pp. 137-8.

29 Joseph D. Straubhaar, 'Television and Video in the Transition from Military to Civilian Rule in Brazil', Latin American Research Review, 24:1 (1989), p. 141.
} 
by $1972 . .^{30}$ By then it had already obtained the advantages it needed from the relationship. Globo was producing high quality programmes through the technology transfer with 'Time Life' that would cost its competitors time and money to copy. As a consequence Globo began to dominate advertising revenue from an early stage with some figures suggesting that it captures around 80 per cent of total advertising revenue for TV in Brazil. ${ }^{31}$ This is a figure greater than that enjoyed by any media corporation in a national commercial market in the rest of the world. Further, Globo received no additional punishment for its illegal 'Time Life' deal, despite the protestations of its competitors, reflecting its relationship with the military regime.

Globo's relationship to the military evolved in this period as the company grew in terms of its economic, political and cultural power. In the early years of the dictatorship Globo was largely dependent on the military for its commercial success. The military regime acted to block Globo's competitors through its control of the issuing of licences and the use of censorship. ${ }^{32}$ This made perfect sense within the context of a programme of conservative modernisation. The military needed Globo to help develop the ideational infrastructure that would establish Brazil's national identity. In practice the state established a monopoly control over the establishment of a communications infrastructure allowing Globo as a private actor to take over the most profitable and promising area of the media that was not to be monopolised: broadcast television. ${ }^{33}$

Globo began to develop local production of its programmes, most importantly its telenovelas, which became the centrepiece of broadcasting in Brazil. The format of telenovellas tended to be melodramatic storylines, usually portraying elites in Brazil. Analysts across the political spectrum viewed the telenovella in this period as constructed to portray a positive image of Brazil under the military and its 'economic miracle'. ${ }^{34}$ At present Globo broadcasts three nightly telenovellas that capture 30-35 per cent of all TV revenues and earn $\$ 32 \mathrm{~m}$ annually in sales to 52 countries. ${ }^{35}$ The telenovella has been examined by a number of writers who have seen them as an important public forum for the introduction of social issues in Brazil, from the impact of political corruption to more recently the expression of gay rights and homosexuality. ${ }^{36}$ As we will see, telenovellas have also been vehicles for overt propaganda during the Presidential elections after Brazil returned to democracy.

However, by the 1970s the military began to grow wary of Globo and its power and made moves to challenge its authority. Whilst the company remained preeminent, the military allowed a number of Globo's rivals to develop as a counterweight to the monopolistic position of the company. In this phase the relationship began to change from one in which Globo was overwhelmingly dependent on the

30 John Sinclair, Latin American Television: A Global View (Oxford: Oxford University Press, 1999), p. 67.

31 Helen Sousa, 'Crossing the Atlantic: Globo's Wager in Portugal', 〈http://ubista.ubi.pt/ comum/ sousa-helena-globo-wager-mexico.html $\rangle$, last viewed 20 April 2006.

32 Henry, The Blood Bankers, pp. 137-8; Sinclair, Latin American Television, p. 68.

33 Sergio Mattos, The Impact of the 1964 Revolution on Brazilian Television (San Antonio: Klingensmith, 1982).

34 Straubhaar, 'Television and Video in the Transition', p. 144.

35 Michael Kepp and Mike Zellner, 'The Empire Strikes Again', Latin Trade (April 2000), 〈http://www.findarticles.com/p/articles/mi_m0BEK/is_4_8/ai_61601027〉, last viewed 16 April 2006.

36 Straubhaar, 'Television and Video in the Transition', p. 149. 
military for its development to a codependent relationship where each side had something to gain, and something to lose, from the power of its partner. ${ }^{37}$

By 1975 Globo was a major media corporation and sought to assert itself by moving into the international market. This is where the geolinguistic aspect of the world system emerges. Globo has the advantage of the domination of a huge commercial market in Brazil but the disadvantage that its primary language is Portuguese. Although Portuguese is spoken by over 200 million people globally, it places limits on the geolinguistic market reach of Globo's programming. Compared to Televisa in Mexico, for example, Globo faces a major geolinguistic hurdle. It has to dub its programmes into other languages (Spanish and English) at great cost if it is to take full advantage of overseas markets. Its first move was to sell telenovellas to Portugal from 1976 onwards and they became massively successful. This was followed in 1985 by investment in TV Monte Carlo with a view to broadcasting to Portuguese speaking communities in Italy, although it subsequently sold this in 1994. ${ }^{38}$ Part of the economic weakness of Globo in this period was due to its position as a company based in a state moving from the periphery to the semi-periphery of the world system, one which suffers regular financial and currency crises.

The period of conservative modernisation had succeeded in pushing Brazil into the semi-periphery but at major social cost and without addressing the structural problems affecting the country. In effect, it was development built by debt, and the creditors were now demanding their money back. ${ }^{39}$ The military regime had lost what legitimacy it had because of its economic incompetence and its political authoritarianism. ${ }^{40}$ What was Globo's position to be as the pro-democracy movement began to make inroads in Brazilian political culture?

\section{Globo in the age of global communication: 1985 onwards and the return to democracy}

By the late 1970s Brazil's much-vaunted economic miracle had collapsed in a welter of debt and corruption with little to show for it by way of resolving the country's long-standing social conflicts. In effect, the military regimes that had ruled since 1964 had used their coercive power to co-opt elites and repress the majority of the population who remained mired in the direst poverty in all the semi-periphery. Globo had assumed the role of defender of the military regimes in return for favourable treatment that had enabled the company to grow into a monopolistic national media organisation with the potential to compete internationally. But the decline of the military regimes brought a dilemma for Globo as it now had to confront the possibility of a very different kind of political and economic order. The prodemocracy movement that began its campaign in 1984 was an expression of the diverse grassroots movements in Brazilian civil society that emerged in the 1970s. ${ }^{41}$

37 Ibid., p. 142; Sinclair, Latin American Television, p. 69.

38 De Melo, 'Development of the Audiovisual Industry in Brazil'.

39 Edmar L. Bacha and Pedro S. Malan, 'Brazil's Debt', in Alfred Stepan (ed.), Democratising Brazil.

40 Bertha K. Becker and Claudio A. G. Egler, Brazil: A New Regional Power in the World-Economy, ch. 6 .

41 Margaret E. Keck, The Workers' Party and Democratisation in Brazil (London: Yale University Press), ch. 2. 
Its goals were a challenge to the elite-led and anti-democratic political culture that had hitherto shaped Brazilian society.

Whilst its rivals gave coverage to the pro-democracy movement and the series of large-scale rallies taking place throughout the country, Globo initially chose to ignore it. Indeed, when it did cover one of the rallies that took place in Sao Paulo in 1984 it portrayed it as part of a city festival. ${ }^{42}$ Globo was initially determined to stay loyal to the military regime. However, its lack of coverage of the pro-democracy campaign garnered criticism from inside and outside the organisation. Journalists working for Globo pointed out that it was destroying the credibility of the company to be ignoring or misrepresenting the campaign. ${ }^{43}$ There is also evidence that Globo's management became increasingly angered by military censorship of their programming. ${ }^{44}$ As it became clear that the pro-democracy movement would win both its call for a plebiscite and the plebiscite itself, and that the military had in turn largely lost the will to govern the chaos that they had made of Brazilian society, Globo made an important strategic decision: it decided to cover the campaign. Turning its criticisms onto the military, Globo began to cover the pro-democracy movements' rallies and the debates that ensued, and began to renegotiate its role in Brazilian political culture. If there was to be a return to democracy Globo needed to secure its monopoly over Brazilian popular and political culture and its relationship with the newly emerging political order. ${ }^{45}$ As Straubhaar comments, this does not mean that Globo actively supported the campaign, rather it was a pragmatic decision based on its commercial interests. ${ }^{46}$

The successful plebiscite that took place in 1985 led to an interim period of three years during which a new constitution for Brazil was to be established. In effect Brazil's established social and political elites were able to use this period to try to contain the democratic movement so that it could not fundamentally challenge existing forms of wealth and power. Rather, the option for the pro-democracy movement was to work with the elites. Globo's position during this transition was crucial as the interim President was to be Tancredo Neves, a man who fully recognised the power of Globo when he said during a fight over the appointment of his communications minister (a former Globo employee) 'I'll fight with the army minister, but not with Roberto Marinho' ${ }^{47}$ Neves died shortly before he was due to take office and his position was taken by José Sarney, another figure with links to Globo, illustrating the far-reaching political power of the company. ${ }^{48}$ Indeed, there is anecdotal evidence to suggest that Marinho's political influence by this stage was so great that he actually interviewed potential ministers for the interim administration. ${ }^{49}$

42 Straubhaar, 'Television and Video in the Transition', p. 145; Luis Felipe Miguel and Paolo Simoes, 'The Globo Television Network and the Election of 1998', Latin American Perspectives, 27:6 (November 2000), p. 71.

43 Straubhaar, 'Television and Video in the Transition', p. 146.

44 Ibid.

45 Roberto Amaral, 'Mass Media in Brazil', in Elizabeth Fox and Silvio Waisbord, Latin Politics, Global Media, p. 39.

46 Straubhaar, 'Television and Video in the Transition', p. 147.

47 BBC News, 'Brazilian Media Magnate Dies', 7 August 2003, 〈http://news.bbc.co.uk/1/hi/world/ americas/3130983.stm〉, last viewed 17 April 2006.

48 Venicio A. de Lima, 'The State, Television and Political Power in Brazil', Critical Studies in Mass Communication, 5 (1988), pp. 108-28.

49 Fernando Rodrigues, 'Brazil: Corruption Notebook', 6 July 2004, Global Integrity Report 2004, $\langle$ http://www.globalintegrity.org/2004/country.aspx?cc=br\&act=notebook $\rangle$, last viewed 20 April 
Globo and Brazil's elites were to face a dramatic new challenge in this period as the left could formally contest elections again in Brazil and in the form of the Workers' Party (PT) the left had a representative with longstanding roots in major social movements. ${ }^{50}$ Composed of a variety of leftist groups and social movements the PT espoused a mixture of leftist policies and a commitment to a Gramscian strategy of a 'war of position' to build a long-standing coalition of social forces that would eventually take over the Brazilian state and direct it towards socialist ends. ${ }^{51}$ It is hard to overestimate the significance of the PT for Brazilian political culture, as no such leftist political party had been allowed to exist before. ${ }^{52}$ At the same time Globo faced new competition from within Brazil and internationally as the impact of New Information and Communication Technology (ICT) took hold.

The age of globalisation has brought two major challenges to the semi-periphery in general and to Brazil and Globo in particular: first, globalisation has been synonymous with democratisation. ${ }^{53}$ The end of the Cold War saw a wave of democratisation across Eastern Europe but this process had already begun in other parts of the world such as Brazil. Nonetheless, this democratisation has not resolved the social conflicts that characterise the world system; it has merely relocated them to a different level. The danger for the neoliberal elites attempting to drive this process is that democracy is not easy to control, as the rise of the PT in Brazil illustrates. Second, the globalisation of capital (the liberalisation, privatisation and deregulation of financial markets) and of new information and communication technologies, has led to particularly fierce contests in global media markets and this has presented a strategic problem for Globo. Globo needed to move into the new communication market-place emerging in Brazil that will ultimately link the convergence of telecommunications, computers and mass media (telematics). How could it compete with media organisations from the core without attracting foreign investment that might see the Marinho family and Brazilian elites lose control of the company? How would Globo deal with these twin threats?

Starting with the political threat posed by a newly revived left in Brazil, Globo moved to the position of gatekeeper to Brazilian political culture. If the left were to contest Brazil's Presidential, congressional and state elections then Globo would use its power to do everything to discredit them. There was to be a parameter of legitimate political debate and ideas and the leftist populism of the PT and its allies fell well outside that framework. In practice this meant two things for Globo: propaganda to discredit the left, particularly the PT Presidential candidate Lula; and at the same time support for the alliance of establishment parties. Globo's propaganda was quite stark and is illustrated by a variety of examples. When the first formal presidential election campaign was under way in 1989 Globo smeared Lula's candidacy, accusing him and his party of being communists working for the Soviet

2006. On Globo's political power, see Venicio A. de Lima, 'The State, Television and Political Power in Brazil'.

50 Keck, The Workers' Party and Democratisation in Brazil.

51 Pablo Ortellado, 'Brazil: Between Hope and Fear', Znet, 25 November 2002, 〈http://www.zmag.org/ content/showarticle.cfm?ItemID=2665), last viewed 20 April 2006.

52 Sader and Silverstein, Without Fear of Being Happy, ch. 1.

53 Robert McChesney, 'Global Media, Neoliberalism and Imperialism', Monthly Review (March 2001). 
Union in standard 'red scare' fashion. ${ }^{54}$ More powerfully, they ran a story in which they accused Lula of forcing a former partner into having an abortion, a significant smear in a country dominated by the Catholic Church. ${ }^{55}$ In addition to this, Globo sought to build up the candidacy of Fernando Collor as the outsider who would sweep away the corruption of Brazilian politics. Collor's campaign was a mixture of the honest and incorruptible outsider and the glamorous media-friendly playboy. The aim was to present a charismatic figure that would unite and help lead a new consensus around the need for neoliberal reforms that would cut across class lines. Needless to say, Collor had strong links with Globo. ${ }^{56}$ The key programme for setting the agenda for political debate and framing the dominant meaning for events and issues remains Globo's long-running Jornal Nacional (on air since 1969), watched daily by 50 million Brazilians. ${ }^{57}$

By comparison, Lula appeared to be a rough, poorly educated and old fashioned figure, ill-suited to a media-driven age, led, of course, by Globo. As Lima has written, Globo ran three telenovellas during the course of this campaign that featured story-lines favourable to Collor in which the handsome outsider arrives in town and takes on the corrupt forces that govern it. ${ }^{58}$ The final attempt to undermine Lula came with the presidential candidate head-to head TV debates. Globo was accused by its critics of selecting clips that showed Collor in the best possible light and Lula in the worst..$^{59}$ Despite the barrage of propaganda it has to be noted that the PT did very well in this and subsequent elections, indicating the strength of their social movement as an alternative network of communication, as well as the limitations of Globo's power as a monopolistic media corporation. Globo's anti-leftist propaganda continued in subsequent Presidential elections in 1994 and 1998, even after the resignation and near-impeachment of Collor and the ultimate failure of the Cardoso administration to solve Brazil's economic crises. The official public sphere in Brazil remained a guided forum within which the commercial media in general and Globo in particular held power of selection and representation of issues. Such was Globo's paranoia regarding its role and image as gatekeeper to the Brazilian public sphere that in 1993 it bought the rights to the documentary 'Beyond Citizen Kane', made by Simon Hobart, in order to prevent it being shown. Hobart's documentary was an unfavourable account of the political power and influence of Globo in Brazil.

What then of the commercial challenge from globalisation to Globo in this period? Brazilian media ownership had been locked in a familiar pattern of family-dominated ownership structures and state protection. Whilst these had been important for the development of Globo during the period of dictatorship, the globalisation of finance and investment and the intensification of competition, in what are increasingly global media markets, presented a new challenge. Globo's strategy in response to this was

54 Venicio A. de Lima, 'Brazilian Television in the 1989 Presidential Election: Constructing a President', in Thomas Skidmore (ed.), Television, Politics and the Transition to Democracy in Latin America (Washington, DC: Woodrow Wilson Centre Press), pp. 97-117.

55 Pablo Ortellado, 'Brazil: Between Hope and Fear'.

56 De Lima, 'Brazilian Television in the 1989 Presidential Election'; Armando Boito and Laura Randall, 'Neo Liberal Hegemony and Unionism in Brazil', Latin American Perspectives, 25:1 (1998), pp. 71-93.

57 Luis Felipe Miguel, 'The Globo TV Network and the Election of 1988', Latin American Perspectives, 27:6 (2000), pp. 65-84; John Sinclair, Latin American Television: A Global View, p. 69.

58 Venicio A. de Lima, 'Brazilian Television in the 1989 Presidential Election: Constructing a President', in Skidmore (ed.), Television, Politics and the Transition, pp. 105-6.

59 Miguel and Simoes, 'The Globo Television Network and the Election of 1998', p. 71. 
two-fold. First, it remained committed to high-quality production in its domestic markets, hoping to hold off its competitors through the quality of the shows it produced. ${ }^{60}$ To a large extent this has been a successful strategy in that despite the increasing power of some of Globo's competitors it remains by some distance the pre-eminent broadcaster in Brazil. This can be measured in terms of the quantity of shows produced and the money it spends on producing them, as well as the percentage of advertising revenue it continues to secure. Globo has the largest reach of any Brazilian broadcaster, reaching approximately 99.9 per cent of the potential national audience. ${ }^{61}$ This domestic strategy was further enhanced through the 1996 Telecommunications Act that consolidated cable distribution rights in Brazil under a duopoly of Globo and its main but subordinate competitor Abril. ${ }^{62}$ Although slow to act in the new technology market compared to Abril, Globo has had the financial power to catch up through its use of strategic partnerships. ${ }^{63}$ Ultimately it was Globo's investment in cable and the internet that led to its financial crisis at the end of the millennium. ${ }^{64}$

Second, although the consolidation of Globo's domestic market position was secure, the problem of global competition and debt remained. How was it to secure the investment needed to create the cable and internet infrastructure it wanted to build in Brazil? In order to achieve this, Globo pursued a series of unprecedented partnerships with companies from the core such as Microsoft and News Corporation to help fund the Direct to Home (DTH) satellite broadcasting and cable infrastructure. ${ }^{65}$ It also borrowed heavily from North American banks. In order to secure the foreign investment it needed Globo had to push for a change in the Brazilian constitution that would allow for greater foreign investment (49 per cent) in Brazilian companies, the law that had been illegally breached in its earlier deal with 'Time Life'. The introduction of new Information, Communication and Technology markets (Cable, Satellite, Pay-per-view, the Internet) in Brazil have been dominated by the already powerful media corporations, the most important of which, as Amaral notes, is Globo. ${ }^{66}$

These challenges to Globo were taking place against a background of inter-elite conflict in Brazil between those pushing to implement neoliberal reforms and those hoping to preserve the more traditional mixture of free trade and state-protectionist policies. Brazil introduced a series of neoliberal changes after 1989: reforming the domestic financial system in 1989; liberalising international capital flows 1989-1992; liberalising foreign trade 1990-94. ${ }^{67}$ Between 1996 and 2002 Brazil's privatisation

${ }^{60}$ Allesandra Dalevi, 'The Owners of Brazil'. Unlike other South American countries the Brazilian TV market is dominated by domestic programmes rather than imports. Globo shows 98 per cent domestic content during its primetime. Jo Johnson, 'The United States of Television', The Financial Times, 21 July 2003.

61 BBC News, 'Brazilian Media Magnate Dies', 7 August 2003, 〈http://news.bbc.co.uk/1/hi/world/ americas/3130983.stm>, last viewed 17 April 2006.

62 Abril is the largest publishing company in South America, controlling around 67 per cent of the Brazilian publishing market. See John Sinclair, 'The Globalisation of Latin American media', NACLA, 37:4 (January/February 2004), p. 16.

63 Sinclair, Latin American Television: A Global View, pp. 74-5; Kepp and Zellner, 'The Empire Strikes Again'.

64 Alexandra Kirkman, 'Brazil's Big Picture', Forbes.com, 〈http://www.forbes.com/global/2000/0501/ 0309042a.html>, last viewed 20 April 2006.

65 Kepp and Zellner, 'The Empire Strikes Again'.

66 Amaral, 'Mass Media in Brazil'.

${ }^{67}$ Saad-Filho, 'New Dawn or False Start in Brazil?', p. 11. 
programme attracted \$US30 bn which was spent on the purchase of the best public-sector industries: gas, electricity, financial and telecommunications. ${ }^{68}$ The appeal of neoliberalism was strong in Brazilian political culture from Collor through Itamar Franco to Cardoso as it carried a potent anti-statist and pro-individual freedom message. ${ }^{69}$ In a country recovering from two decades of military rule and endemic corruption it is not difficult to understand the rhetorical appeal that such an ideology would have across the social spectrum.

The impact of these neoliberal policies was initially attractive to Globo too as it meant it would be increasingly able to establish strategic partnerships with core companies in order to maximise its international appeal. By this stage Globo had developed into a major global corporation placing it in the second tier of global media firms. ${ }^{70}$ Nonetheless, there were problems for Globo that could not be resolved by the actions of the company alone. Two major problems placed the company in unprecedented difficulties by the end of the millennium: the corruption and incompetence of the establishment parties running Brazil's new democratic political culture was clear for all to see. Successive administrations had failed to address Brazil's social and economic problems and corruption remained a major structural feature of politics. This is illustrated by the dispersal of TV and radio licences in Brazil as mechanisms to gain political support for the state. As Fox notes, of the 302 licensed commercial TV stations in 1995, 94 were owned by politicians or ex-politicians, and 1,169 out of 2,908 radio stations. ${ }^{71}$ The rise of the PT as a socialist alternative was a genuine threat to Globo and the political system. Second, the failure of democratic administrations led to a major financial crisis in 1997-98 as part of a series of globalised financial crises that started in the Far-East (Thailand) and spread to Eastern Europe and South America. The globalisation of Information and Communication Technologies (ICTs) was to lead, as Harvey has noted, to the compression of time and space, in practice intensifying the speed and volume of capitalist transactions and placing states outside the core increasingly at the mercy of global capital flows. ${ }^{72}$ As a consequence, Brazil's currency was massively devalued and Globo suddenly found itself on the point of defaulting on its loans to North American banks. ${ }^{73}$ Globalisation and neoliberalism had turned out to be disciplinary processes for both the public sector and the private sector alike and Globo was in a deep crisis. According to the Forbes annual billionaire survey, in 2000 the Marinho family had been worth \$US6.4 bn. By 2002 they were down to less than \$US1 bn. Globo's income had deteriorated from \$US260 m per annum in 2000 to \$US21.1 m in 2001. ${ }^{74}$ Globo had debts of around \$US3.2 bn, 55 per cent of the debt of all Brazilian media. ${ }^{75}$

68 Paul Flannigan, 'Lula, Brazil and the Future of the Left', Socialist Democracy (June 2004), 〈http://www.socialistdemocracy.org/Brazil/BrazilChapter1.htm〉, last viewed 20 April 2006.

69 Peter R. Kingstone, Crafting Coalitions for Reform: Business Preferences, Political Institutions and Neoliberal Reform in Brazil (Pennsylvania, PA: Pennsylvania State University Press, 1999), chs. 2, 5 and 6.

70 Robert W. McChesney and Ed Herman, The Global Media (London: Cassell, 1997), ch. 1.

71 Elizabeth Fox and Silvio Waisbord, 'Latin Politics, Global Media', in their Latin Politics, Global Media (Austin, TX: University of Texas Press, 2000), p. 10.

72 David Harvey, The Condition of Postmodernity (London: Blackwell, 1989), p. 240.

73 Saad-Filho, 'New Dawn or False Start in Brazil?', pp. 3-21; Henry, The Blood Bankers, p. 141.

74 Raymond Collitt, 'Investment in Brazil's Media Set to Open Up', The Financial Times, 29 May 2002.

75 Carlos Castilho, 'Globo: Death of a Brazilian Media Empire?', MediaChannel.org, 6 July 2004, 〈http://www.mediachannel.org/views/dissector/affalert167.shtml〉, last viewed 20 April 2006. 
The impact of economic globalisation was to render the semi-periphery even more vulnerable to currency crises and deepening inequality. ${ }^{76}$ In Brazil the richest 10 per cent of the population receive 46.7 per cent of earnings and the bottom 10 per cent receive only 0.5 per cent. ${ }^{77}$ The ultimate failure of the lauded 'Real Plan' might have led to Cardoso's defeat in the 1998 Presidential election but proved instead to be another example of Globo's power to frame the news in Brazil. As Miguel and Simoes argue, Globo sought to turn the economic crisis into a triumph for Cardoso by insisting it was caused by the actions of globalisation over which Cardoso could have little control. What's more, only Cardoso possessed the experience needed to steer Brazil through this crisis. ${ }^{78}$

By the time that the PT candidate Lula was elected as President of Brazil in 2002 Globo had already positioned itself to cope with a President who had good reasons for regarding them as a major obstacle to his reform programme. The mainstream political figures in Brazilian political culture had been discredited by the failures of successive post-democracy administrations. ${ }^{79}$ Corruption remained a deeply-rooted problem and the living conditions of the majority of Brazilians remained the worst in the semi-periphery. The Marinho family had made overtures to the PT, and a number of important changes had taken place since the 1998 Presidential elections that suggested the threat of a Lula Presidency to Globo and Brazil's elite was more rhetorical than real. After the 1998 election the PT began to change its political rhetoric and a section of its left-wing were expelled from the party. ${ }^{80}$ Lula himself had a transformation of image to make him appear more modern and mainstream to voters and he committed himself publicly and often to the IMF packages agreed to by his predecessors. ${ }^{81}$ In order to be credible with Globo and international financial institutions Lula abandoned substantive social commitments in key areas of his programme and placed 'economic stability' before anything else. ${ }^{82}$ So far did Lula shift his political position that Globo and

76 Saad-Filho, 'New Dawn or False Start in Brazil?', pp. 3-21. See the UN Development Report 2003, 'Millennium Development Goals' (New York: Oxford University Press, 2003) for an analysis of the impact of economic globalisation. Brazil is second only to South Africa in the World System in terms of income inequality, World Bank Country Brief, December 2005, 〈http://web.worldbank.org/ WBSITE/EXTERNAL/COUNTRIES/LACEXT/BRAZILEXTN/0,,menuPK:322351 pagePK: 141132 iPK:141107 theSitePK:322341,00.html>.

77 Arthur Ittuassu, 'Lula and Brazil', Open Democracy, 19 May 2005, 〈http://www.opendemocracy.net/ debates/article.jsp?id=3\&debateId=33\&articleId=2521 $\rangle$, last viewed 20 April 2006.

78 Miguel and Simoes, 'The Globo Television Network and the Election of 1998', pp. 68-82.

79 Saad-Filho, 'New Dawn or False Start in Brazil?', pp. 3-21. William Perry, 'Brazil Alert', Center for Strategic and International Studies, 9:7 (30 October 2001), 〈http://www.csis.org/media/csis/pubs/ hf_v09_07.pdf $\rangle$; Burbach, 'Another World is Possible'.

${ }^{80}$ Comment, 'Brazil: Lula Starts to Purge the Workers' Party', Workers Liberty, 2 June 2003, 〈http://www.workersliberty.org/node/966〉, last viewed 18 April 2006. Comment, 'A Political Purge in Brazil', The Economist, 18 December 2003, 〈http://www.economist.com/displayStory.cfm? Story_ID $=\mathrm{S} \% 27 \% 298 \% 20 \% 2 \mathrm{CP} \% 217 \% 25 \% 21 \% 20 \% 21 \% 5 \mathrm{C} \% 0 \mathrm{~A}\rangle$, last viewed 18 April 2006. Charles Andre Udry, 'The Workers' Party in power', Workers' Liberty, 22 February 2003, $\langle$ http://www.workersliberty.org/node/669〉, last viewed 18 April 2006.

81 Saad-Filho, 'New Dawn or False Start in Brazil?', pp. 3-21, argues that Lula's programme is more nationalist than socialist.

82 Desmond Lachman, 'Lula Still Needs the IMF', American Enterprise Institute, 31 July 2003, 〈http://www.aei.org/publications/pubID.18911,filter.economic/pub_detail.asp〉, last viewed 19 April 2006. Bill Vann, 'Brazil's Lula Reassures Wall Street, Warns Workers of Austerity', World Socialist Web site, 31 October 2002, 〈http://www.wsws.org/articles/2002/oct2002/braz-o31_prn.shtml〉, last viewed 19 April 2006. 
significant sections of Brazil's capitalist class were able to endorse his candidacy in the 2002 election. ${ }^{83}$

In truth Lula faced an unenviable position as President: he was inheriting a state and social institutions that had been built to defend the social structure of Brazil, not to transform it. ${ }^{84}$ As such it was hardly going to be sympathetic to his more radical ambitions. The threat of the military intervening remained a factor and the power of global capital to destroy the Brazilian economy had been illustrated by the financial crisis of 1997-98. In addition systematic violence against the Workers Party, including assassinations of Mayoral candidates, remains a fact of Brazilian political life. In 2000 alone 65 activists for the Landless Rural Workers Movement (MST) were murdered. ${ }^{85}$ In office the recently re-elected Lula has been a disappointment to many of his supporters and is regularly denounced for selling out his long-standing commitments. ${ }^{86}$ Around 70 per cent of Brazilians remain in poverty. ${ }^{87}$ In addition there have been problems of corruption attached to Lula's administration, though not to him personally, that have led to calls by his opponents for his impeachment. ${ }^{88}$ Thus, Lula has been subject to a range of disciplinary mechanisms at the national and global level that have severely undermined his autonomy to act within the formal framework of Brazil's neoliberal democracy. Finally, the Workers' Party itself has been subject to an ongoing internal ideological fight between those who accept neoliberalism, those that want to modify it and those that fundamentally oppose it. ${ }^{89}$ Globo plays a major part in this in its role as gatekeeper to Brazilian political culture, primarily through two powers: the power to set agendas for discussion and the power to frame the meaning of issues.

As has been seen in many South American countries in the past five years, the rise of nominally leftist governments has highlighted the separation between the social movements that put them into power and the governments themselves. Thus far, only the Chavez government in Venezuela has been significantly radicalised by its grass-roots social movement. ${ }^{90}$ In Brazil and elsewhere the political leadership has attempted to tame and limit the expectations of its grassroots for the time being, though there are signs that this might be changing. ${ }^{91}$ So for Globo the Lula Presidency has proven less of a difficulty than it would have imagined when Brazil first returned to democracy. Indeed, Lula declared three days of mourning for

${ }^{83}$ Immanuel Wallerstein, 'Hope Conquered Fear', Commentary No. 100, 1 November 2002, $\langle$ http://www.binghamton.edu/fbc/100en.htm〉, last viewed 17 April 2006.

84 Gilles De Staal, 'Brazil: No Economy without Democracy' Le Monde Diplomatique, December 2003, 〈http://mondediplo.com/2003/12/11 brazil〉, last viewed 15 August 2007.

85 Ibid. Roger Burbach, 'Another World is Possible', Z Magazine, October 2002, 〈http:// zmagsite.zmag.org/oct2002/burbach1002.htm〉, last viewed 15 August 2007.

86 Reuters, 'Don't Worry, Be Patient, says Brazil's Lula', ABC News, 5 July 2004. Comment, 'Brazil's economy', The Economist, 27 May 2004.

87 Andreas Hernandez, 'Brazil's New Deal Foreign Policy', Peace Work, February 2004, 〈http:// www.afsc.org/pwork/0402/040211.htm〉, last viewed 18 April 2006.

88 Norman Madarasz, 'The Choking of Brazil's Worker Party', Counterpunch, 9/10 July 2005, $\langle$ http://www.counterpunch.org/madarasz07092005.html〉. Hilary Wainwright, 'Lula's Lament', Red Pepper, October 2005.

89 Joao Pedro Stedile of the MST, 'Three Directions in Brazil', Znet, 22 October 2003, $\langle$ http://www.zmag.org/content/showarticle.cfm?ItemID=4380〉, last viewed 18 April 2006.

90 Chris Harman, 'Revolution in the Air', Socialist Review, December 2005, 〈http:// www.socialistreview.org.uk/article.php?articlenumber $=9617\rangle$.

91 Roger Burbach, 'Rebuffing the IMF', Counterpunch, 25 March 2004, 〈http:// www.counterpunch.org/burbach03252004.html〉. 
Roberto Marinho when he died in August 2003.92 By all indicators Lula has performed to a level that has garnered support from international financial institutions and significant sections of Brazil's elites, including pursuing steeper cuts in public spending than those demanded by the IMF. ${ }^{93}$

Thus the globalisation of democracy has not, so far, caused Globo the dilemmas it might have anticipated from a PT Presidency. Instead, the bigger problem it has faced was caused by the impact of neoliberal policies within Brazil and across the world system. As noted in the previous section, by November 2002 the Brazilian currency had depreciated 38.7 per cent in that year alone and Globo was forced to file for bankruptcy protection to rid itself of its \$US1,500 m debt. ${ }^{94}$ This led it to sell off parts of the company as a means of restructuring its debt and in 2003 it lobbied the state to offer financial support in the form of a long-term low-cost loan. ${ }^{95}$ This was one area where Lula could bring pressure to bear on Globo as he could quite reasonably refuse the loan on the grounds that it was an illegitimate interference in the workings of the market. Neoliberal principles could be used to bite Globo and force it to pursue different options.

Given its hold over the Brazilian media market, Globo was always a potentially attractive investment for capitalists from the core and with the Real devalued by the currency crisis of 1997-98 it was an increasingly affordable one. ${ }^{96}$ In effect the restructuring package that Globo eventually organised was made possible by the deeper integration of Brazil into the economic order of the world system. As Brazil liberalised its economy and reformed its domestic law to allow for greater foreign investment, Globo was open to forms of partnership that would previously have been far more limited in scope. ${ }^{97}$ In February 2002 the House of Representatives passed a constitutional amendment allowing Brazil's media companies to open themselves to foreign ownership of up to 30 per cent of their total share capital. As something of a compromise to Brazil's more protectionist history, editorial control of the companies must remain in the hands of a Brazilian citizen or naturalised Brazilians of ten years' standing. In addition, Brazil's written and broadcast media can now be managed by legal entities. Prior to this only natural persons could do so. The significance of this is that it provides a mechanism enabling Globo and other Brazilian media to attract capital from the core and to transform the ownership and management of the company out of the hands of the Marinho family into a partnership with other capitalists. ${ }^{98}$ The limitation of it so far is that capital in the core views debt-ridden media corporations in the semi-periphery such as Globo as a

\footnotetext{
92 Alex Bellos, 'Roberto Marinho', The Guardian Newspaper, 8 August 2003, 〈http:// www.guardian.co.uk/brazil/story/0,,1014553,00.html, , last viewed 20 April 2006.

93 Richard Adams, 'American Presidents all Mixed Up', The Guardian Newspaper, 6 July 2004. Sue Branford, 'The Bankers Think they've Tamed Lula', The Guardian Newspaper, 10 July 2003.

94 LatAm, 'Brazilian TV O Globo HQ declares Chapter 11 to Get Rid of Debts', Digest.Liderdigital.com, 7 November 2002, 〈http://www.digest.liderdigital.com/noticias/ detalle_noticia.php?id_noticia=15〉, last viewed 17 April 2006.

95 Carlos Castilho, 'Globo: Death of a Brazilian Media Empire?', Mediachannel, 1 April 2004, $\langle$ http://www.mediachannel.org/views/dissector/affalert167.shtml〉, last viewed 15 August 2007.

96 Mike Kepp, 'Massive M and A Madness?', Latin Trade, 10 October 2002, 〈http:// www.findarticles.com/p/articles/mi_m0BEK/is_10_10/ai_93230207〉, last viewed 14 April 2006.

97 On changes to Brazil's laws on mergers and acquisitions, see the interview with Paulo Cezar of Barbosa Müssnich and Aragão in International Financial Law Review, July 2004.

98 Eliana Maria Filippozzi, 'Foreign Investments in Brazilian Media Approved', International Financial Law Review, April 2002.
} 
potentially risky investment. ${ }^{99}$ In May 2005, after three years of negotiations, Globo finally concluded its restructuring package, Brazil's largest ever corporate bond restructuring. $\$ 1.23$ bn of debt was restructured with its investors accepting a mixture of cash and bonds, enabling Globo to avoid selling the TV stations that it put up as collateral for the initial loans. ${ }^{100}$

The death of Roberto Marinho in 2003 formalised the takeover of the company by his three sons that had in effect been in place for some years. Reports suggest some tension within the family as to the future direction that Globo will take but it is hard to see how it can develop further without becoming increasingly subordinate to and integrated with capital from the core of the world system. Despite Globo's power and Brazil's potential core status, the continuing debt crisis and the subordination of social and economic policy to core-controlled international financial institutions illustrates starkly the vulnerability of even the most powerful states and companies in the semi-periphery to a system that they neither built nor significantly control. ${ }^{101}$ It seems safe to say that Globo's position as gatekeeper to Brazilian political culture will remain but that its effectiveness in that role will be limited by the reality of life in Brazil for the majority. The social movements that propelled Lula to the Presidency will not disappear and their demands cannot be ignored indefinitely, a problem that the ideological power of Globo cannot hide.

\section{Conclusions: The challenges of the globalisation of communication for Globo}

I would like to conclude this article by reflecting on the ways in which the issues raised here connect with two of the three main themes of this Issue of the Review of International Studies. The third theme raised in this Issue is a concern with the ways in which International Relations addresses global problems and relates them to the discipline. I am reticent to move too deeply into this subject as it requires an article in itself, but succinctly I would say that WSA raises profound intellectual objections to orthodox international relations as framed by the neo-neo debate. For all its flaws, WSA offers a far more persuasive approach to understanding global problems and issues than orthodox International Relations (IR) theory. Its relationship to IR remains limited in that IR is built on a theoretical framework that provides a very different ontology and epistemology to that of WSA. As Wallerstein has made clear on numerous occasions, WSA rejects both a state-centric model of the world system and positivism as a method for the production of knowledge, both of which are central to the neo-neo debate.

The first theme raised by the Special Issue is a concern with the ways in which international or global studies approach the question of communication. It is more accurate to describe WSA as a form of global studies given that its ontological starting point is the world system as a single unit of analysis. This article illustrates that WSA is sensitive to the ways in which communication becomes a contest of

99 Kepp, 'Massive M and A Madness?'.

100 Economist Intelligence Unit, 'Media: Brazil', 9 May 2005. Private report purchased from the Economist Intelligence Unit, 1 March 2006, order invoice number \#1580213358.

101 Brazil's international debts stand at \$US300 bn and the government has another \$US250 bn in domestic liabilities. Burbach, 'Another World is Possible'. 
representation between different social forces to establish the boundaries of Brazilian political culture. As has been shown, it is the Globo Corporation that has held the dominant communication power in Brazil to frame representations and set an agenda for political discussion, initially in a subordinate relationship with the state, but later assuming a codependent role. Globo has been able to utilise its vast resources to represent a particular idea of Brazil and of legitimate political discourse that tends to reflect the interests of Brazil's elites. The poor and dispossessed are only admitted into these formal, mainstream debates in political culture if they accept the legitimacy of existing social structures, not if they wish to challenge them. The trajectory of Lula's career is illustrative of the ways in which Globo's power of representation can act to help constrain anti-systemic (subaltern) social forces. Again, it needs to be stressed; this power is not permanent or unchallengeable. As I made clear in the article, for all its monopoly of the means of communication and representation in Brazil, there is a vibrant grass-roots oppositional political culture rooted in longstanding social movements that stand in opposition to the social structures that Globo is both part of and acts to defend. These groups represent a very different form of communication network.

The second issue raised in this section regards the mobility of ideas and this connects with the power of representation. Historically Globo has acted with the state to constrain and control the dissemination of ideas through the control of the means of communication and the use of censorship, state violence and propaganda. The move to a democratic system in Brazil has changed this and led Globo to assume the role of gatekeeper in a guided democratic system. At the same time Brazil has become more integrated into the world system and is subject to both pressures from global capital as well as the national and regional pressures of domestic Brazilian social forces. Although there is more space for ideas to be expressed in Brazilian political culture there are now different layers of mechanisms in place that can act to filter acceptable and unacceptable ideas and discourse. This is illustrated by the crisis in Brazil over the failure of the Real Plan, for example, which might have destroyed Cardoso's Presidency if Globo and other national and international media outlets had not been able to make the case that Cardoso was the only figure capable of steering Brazil through this troubled period.

Turning to the second theme of the special issue, what does WSA tell us about the globalisation of communication with regard to Globo and Brazil? The globalisation of communication coupled with the liberalisation of financial markets has seen Globo develop into a major second-tier communication corporation. However, these benefits are mixed for Globo. Globo is a global communication corporation with distinct strategic advantages in the production of particular goods and services. However, its ability to build on these advantages remains limited by Brazil's weakness as a state in the semi-periphery, a state that is particularly vulnerable to the speculative financial control of capitalists in the core. Far more so than India or China, the Brazilian market is still limited by the poverty and inequality in the country and this imposes limits on Globo's ability to grow through domestic sales alone. Its need to form alliances with the likes of Sky and Microsoft and to restructure its debts through banks in the core reflects the limits of Globo's ability to transcend its location in the semi-periphery. 